\title{
Development of motor learning implementation for ischemic stroke: finding expert consensus
}

\author{
Umi Budi Rahayu ${ }^{1 *}$, Samekto Wibowo ${ }^{2}$, Ismail Setyopranoto ${ }^{2}$ \\ ${ }^{1}$ Doctoral Program, Faculty of Medicine, ${ }^{2}$ Department of Neurology, Faculty of Medicine/ \\ Dr. Sardjito General Hospital, Universitas Gadjah Mada, Yogyakarta, Indonesia
}

DOI: http://dx.doi.org/10.19106/JMedSci004904201706

\begin{abstract}
The main purpose of this study was to investigate motor learning implementation for ischemic stroke from experts on the field of motor learning in stroke patients including the neurologist, medical rehabilitation specialists and physiotherapists. To collect the data and answer the research questions, statements were made on the basis of the study of literature and the grains exploration of the statements in the questionnaire using the Delphi Method. Formulation development model was based iteration or judgment of experts. Validation assessment statement grain tested by the Content Validity Ratio (CVR) and Content Validity Index (CVI) was used to analyze the data. The finding clear up that CVR value of each item statement was 1 and the value of $C V I$ also 1 . There were 6 indicators in a 26-point declaration on the implementation of the development model of motor learning intervention for ischemic stroke. Six indicators included basic theories that support the importance of intervention motor learning, motor learning stages, principles of motor learning, dosage, timing of and kinds of motor learning interventions that can be provided as well as application development intervention model motor learning, allowing given for ischemic stroke. In conclusion, based on the content validity of the results of the consensus expert judgments are six indicators of the importance of motor learning application for ischemic stroke.
\end{abstract}

\section{ABSTRAK}

Tujuan penelitian ini adalah mengembangkan model intervensi pembelajaran motorik untuk strok iskemik dengan cara mencari konsensus dari beberapa ahli, yaitu dokter spesialis saraf, dokter spesialis keterapian fisik dan fisioterapis. Pengumpulan data yang berupa butir-butir pernyataan dibuat atas dasar kajian pustaka terdahulu. Eksplorasi mengenai butir-butir pernyataan dalam kuesioner menggunakan Metode Delphi. Perumusan pengembangan model didasarkan penilaian dari para ahli. Validasi penilaian butir-butir pernyataan diuji dengan Content Validity Ratio (CVR) dan Content Validity Index (CVI). Nilai CVR masing-masing butir pernyataan adalah 1 dan nilai CVI juga 1. Terdapat 6 indikator dalam 26 butir pernyataan tentang pengembangan model intervensi penerapan pembelajaran motorik untuk strok iskemik. Enam indikator itu meliputi dasar teori yang mendukung tentang pentingnya intervensi pembelajaran motorik, tahapan pembelajaran motorik, prinsip-prinsip pembelajaran motorik, dosis, waktu pelaksanaan dan macam 
intervensi pembelajaran motorik yang bisa diberikan. Dapat disimpulkan, berdasarkan validitas isi dari hasil konsensus penilaian para ahli terdapat 6 indikator pentingnya penerapan pembelajaran motorik untuk strok iskemik.

Keywords: model development - application of motor learning - ischemic stroke - expert consensus - neurorestoration

\section{INTRODUCTION}

Ischemic stroke is a type of stroke that is most often found, about $80 \%$ of the instances that could be caused by cardio embolism, arterial embolism or blood vessel disease that is small in the brain. ${ }^{1}$ Deaths as a result of stroke reached 5:51 million in 2002 and its $2 / 3$ occur in developing countries. Stroke is also the main cause of disability throughout the life of patients. ${ }^{2}$ The heavy and wide limitations on stroke are caused by motor limitations. Limitations of this motor, which will influence the movement of the control arm and leg on one side ${ }^{3}$ and occurs in about $80 \%$ of patients. ${ }^{4}$ Nearly two thirds of patients after a stroke begins with mobility deficits, after 6 months more than $30 \%$ of patients cannot walk independently but in walking speed and capacity can be increased to approximately $60 \%$ of patients. ${ }^{5}$

Neurorestoration post-stroke is performed to increase neurogenesis, angiogenesis and oligodendrogenesis, which will further improve nerve repair. ${ }^{6}$ Motor learning approach is an effort that can be performed in neurorestoration to get the effect of nerve cell plasticity. Neuroplasticity is the brain's ability to respond to injury by adapting to restore function. ${ }^{7}$ Motor learning has been defined as a set of internal processes associated with practice or experience leading to relatively permanent changes in the capability for skilled behavior. Other that motor learning is when complex processes in the brain occur in response to practice or experience of a certain skill resulting in change in the central nervous system that allow for production of a new motor skill. ${ }^{8}$ Application of motor learning is given based grading neurologic deficits, signs and symptoms in patients. Motor learning has an influence in improve the functional organization of the motor system. Motor skill learning of a repeated sequence altered cortical activation by inducing a more normal, contralateral pattern of brain activation. Taskspecific motor learning may be an important stimulant for neuroplastic change and can remediate maladaptive patterns of brain activity after stroke. Simultaneously mapping changes in motor-related cortical activation and task-related behavioral improvements that reflect motor learning. ${ }^{9}$

It has been developed kinds of interventions with motor learning approach. Begin around the year 1940 with the application of the principle of orthopedic post-stroke by means of contracting and relaxing the muscles. In the 1950 to 1980 s began to develop some interventions based on the theory of neurophysiology. Intervention approaches that develops when it is Bobath Method, Brunnstrom Method, Rood Method, PNF Method and Carr and Shepherd Method. This approach is motor learning refers to the development of nerve regeneration, where the practice is done in any practical active in the context of a specific motor task. After the 1980s a lot of other methods are evolving, in addition to the development of the old concept methods. Developing new methods 
include Bilateral Arm Training, Repetitive Task Training, CIMT, Mirror Therapy, Mental Practice and Biofeedback.

The systematic review that has been done by Pollock ${ }^{10}$ explain that has done a lot of research, but none of rehabilitation approaches are most effective in recovery of function and mobility of patients after stroke. Assessment of compatibility problems of badly needed to formulate various problems the application of this motor learning. Important point's post-stroke motor learning application needs to be formulated. On this study is to find a formula for the development of post-stroke motor learning model to produce nerve cell reorganization in the brain effectively. The method used is the Delphi Method, as a material to test the validity of the statement items based on the previous literature review and the opinions of experts. The purpose of this study is to develop models of motor learning intervention for ischemic stroke by seeking consensus from several experts.

\section{MATERIALS AND METHODS}

The development model of motor learning application based on a number of previous literature (FIGURE 1).

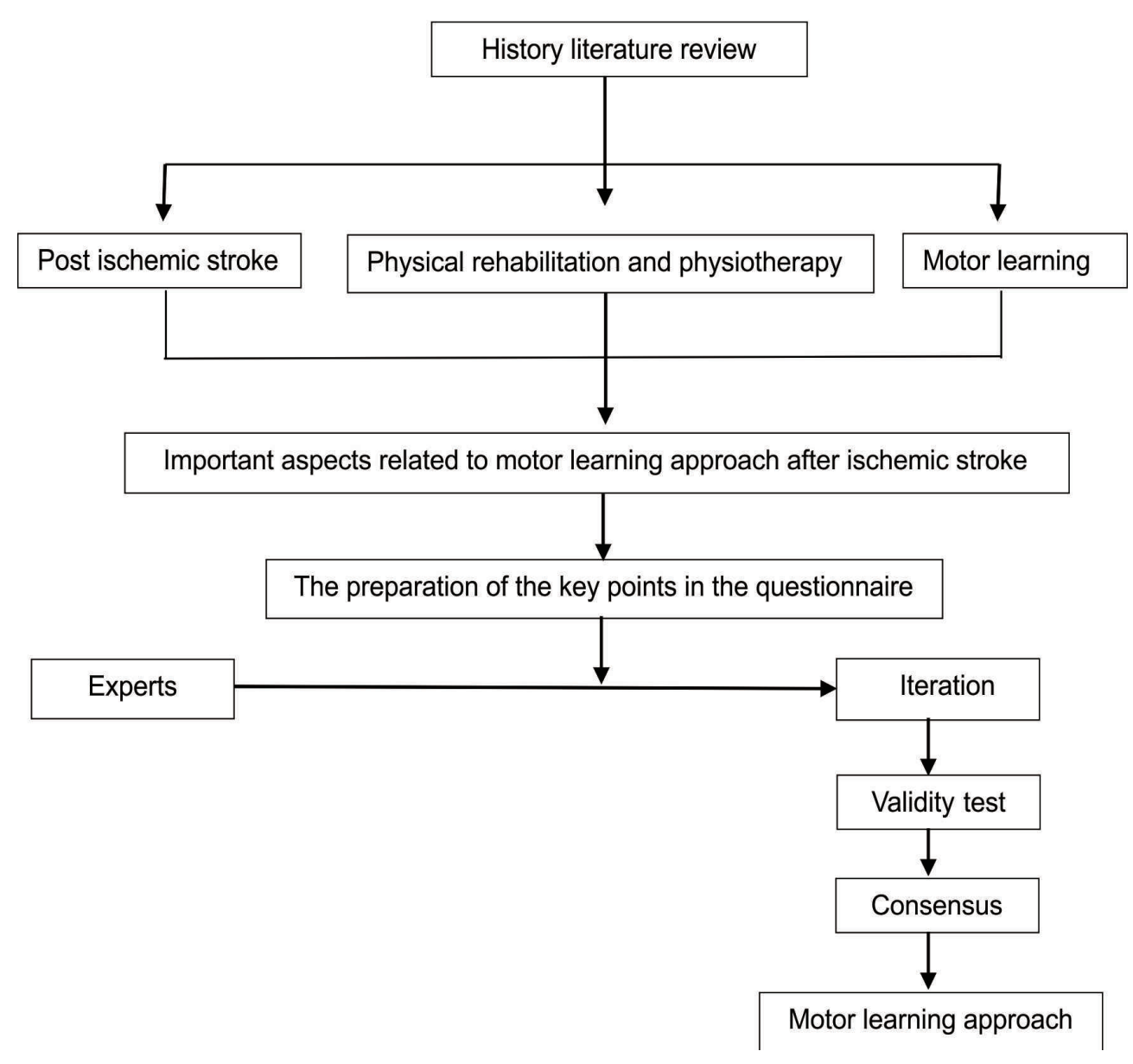

FIGURE 1. Development model of motor learning application 
Literature history and questionnaires in the form of grains of the statement made on the basis of the study of literature. Formulation development grain of motor learning application based on previous literature studies with the keywords: "motor learning", "ischemic stroke", "physical rehabilitation" and "physiotherapy". The grains statement exploration in the questionnaire using the Delphi Method is the way to get a consensus of experts through an intuitive approach. Formulation development model is based iteration or judgment of the experts is to obtain an agreement/consensus.

Delphi Method was done with the following steps: 1). Specifying and identify the problems. In case this is the problem of postischemic stroke and motor learning approach. 2). Choose and identify experts in the fields of neurology, especially stroke. Experts are required in this process is a neurologist, medical rehabilitation specialists, physiotherapists. 3). Designing the questionnaire, by arranging a grain-based instrument observed variables or problems faced. The researcher in charge of designing the questionnaire. 4). Sending the questionnaire, review and analyze the answers instruments that have been restored. Analyses were performed by grouping similar answers. Based on the analysis, further revise the instrument. 5). Development and improvement of the results of the reviews until a few rounds (when needed), by sending back the questionnaire results of revisions to the respondent until a consensus is reached. 6). Create a report on the preparation, process, and results achieved by the Delphi Method.

Formulation development grain of motor learning application based on previous literature studies. Specifications and iden- tification of problems formulated in the point's statement by the researchers based on literature review of previous journals. Beads of important statements consist of post-stroke problems relating to the importance of the motor learning implementation. Select and identify experts in the field of neurology done by qualified expertise. The content validation panel should consist of people who are experts of the domain being studied. ${ }^{11}$ Ideally there should be a variety of experts on a professional level, amounting to 5 to 10 experts. The experts involved in this field is a neurologist, medical rehabilitation specialists and physiotherapists

Questionnaires was build up on the items designed by the researchers on the field and Likert scale five points was used in this study to rate the feeling of the respondents. The grain statements content validity of conducted qualitatively by Delphi Method and quantitative analysis with a Content Validity Ratio (CVR) and the Content Validity Index (CVI). CVR Calculation formula is as followed: $(\mathrm{Ne}-(\mathrm{N} / 2)) /(\mathrm{N} / 2)$. Ne is the number of experts who stated that a very important item, $\mathrm{N}$ is the total number of experts. The CVR value ranking from -1 to +1 . Negative indicates less than half the experts stated that the item was important, positive indicates that more than half the experts stated that it was important item. ${ }^{12}$

\section{RESULTS}

Literature drawn from previous studies by keyword "post ischemic stroke", "physiotherapy and physical rehabilitation" and "motor learning". A number of studies literatures collected is presented in TABLE 1. 
TABLE 1. Previous studies concerning ischemic stroke and its rehabilitation

\begin{tabular}{|c|c|c|}
\hline Authors & Title & Journal \\
\hline Darekar et al. (2015). ${ }^{13}$ & $\begin{array}{l}\text { Efficacy of virtual reality-based intervention on } \\
\text { balance and mobility disorders post-stroke: a } \\
\text { scoping review. }\end{array}$ & $\begin{array}{l}\text { J Neuroeng Rehabil, 12, 46. doi: 10.1186/ } \\
\text { s12984-015-0035-3 }\end{array}$ \\
\hline Hu et al. (2013). ${ }^{14}$ & $\begin{array}{l}\text { The Effect of Post-Stroke Upper-Limb Training } \\
\text { with an Electromyography (EMG)-Driven Hand } \\
\text { Robot. }\end{array}$ & $\begin{array}{l}\text { J Electromyogr Kinesiol, 23(5): 1065-74. } \\
\text { doi: 10.1016/ j.jelekin.2013.07.007 }\end{array}$ \\
\hline Hosp \& Luft, (2011). ${ }^{15}$ & $\begin{array}{l}\text { Cortical plasticity during motor learning and } \\
\text { recovery after ischemic stroke. }\end{array}$ & $\begin{array}{l}\text { Neural Plast. } 871296 . \\
\text { doi: } 10.1155 / 2011 / 871296\end{array}$ \\
\hline Wishart et al. (2000). ${ }^{16}$ & $\begin{array}{l}\text { Application of motor learning principles: The } \\
\text { physiotherapy client as a problem-solver. I. } \\
\text { Concepts. }\end{array}$ & Physiother Can Summer, 229-232 \\
\hline Lehto et al. (2001). ${ }^{17}$ & $\begin{array}{l}\text { Application of motor learning principles: The } \\
\text { physiotherapy client as a problem-solver. IV. } \\
\text { Future directions. }\end{array}$ & Physiother Can, 109-114 \\
\hline Plow et al. (2014). ${ }^{18}$ & $\begin{array}{l}\text { Rethinking stimulation of the brain in stroke } \\
\text { rehabilitation: Why higher motor areas might } \\
\text { be better alternatives for patient with greater } \\
\text { impairments. }\end{array}$ & $\begin{array}{ll}\text { Neuroscience. } & \text { doi: } \\
1073858414537381\end{array}$ \\
\hline Nudo (2011). ${ }^{19}$ & Neural bases of recovery after brain injury. & J Commun Disord, 44, $515-20$ \\
\hline Bernstein $(1996)^{20}$ & With on Dexterity and Its Development & $\begin{array}{l}\text { Lawrence Erlbaum Associates, Publishers } \\
\text { Mahwah, New Jersey, 435-39 }\end{array}$ \\
\hline Muratori et al. (2013) ${ }^{21}$ & $\begin{array}{l}\text { Applying principles of motor learning and control } \\
\text { to upper }\end{array}$ & \\
\hline extremity rehabilitation & $\begin{array}{l}\text { J Hand Ther. } 2013 \text {; 26(2): 94-103. doi:10.1016/j. } \\
\text { jht.2012.12.007 }\end{array}$ & \\
\hline Halsband et al. (2006). ${ }^{22}$ & $\begin{array}{l}\text { Motor learning in man: A review of functional and } \\
\text { clinical studies. }\end{array}$ & $\begin{array}{l}\text { J Physiol, 99, 414-24. doi: 10.1016/j. } \\
\text { jphysparis.2006.03.007 }\end{array}$ \\
\hline Winstein et al. (1997). ${ }^{23}$ & Motor learning after unilateral brain damage. & Neuropsychol, 37, 975-87 \\
\hline Johansson $(2003) .^{24}$ & $\begin{array}{l}\text { Guest editorial: Neurorehabilitation and brain } \\
\text { plasticity. }\end{array}$ & J Rehabil Med, 35, 1 \\
\hline Olaleye et al. (2014). ${ }^{25}$ & $\begin{array}{l}\text { Development and evaluation of the primary } \\
\text { healthcare-based physiotherapy intervention and } \\
\text { its effects on selected indices of stroke recovery. }\end{array}$ & $\begin{array}{l}\text { J Disabil Rehabil, 36(1):49-54. doi: 10.3109/ } \\
\text { 09638288.2013.777804 }\end{array}$ \\
\hline Pollock et al. (2014). ${ }^{26}$ & $\begin{array}{l}\text { Physical rehabilitation approaches for the recovery } \\
\text { of function and mobility following stroke (Review) } \\
\text { Physical rehabilitation approaches for the recovery } \\
\text { of function and mobility following stroke. }\end{array}$ & $\begin{array}{l}\text { Cochrane Lib, 4. doi: 10.1002/14651858. } \\
\text { CD001920.pub3. }\end{array}$ \\
\hline $\begin{array}{l}\text { The AVERT Trial } \\
\text { Collaboration Group, } 2015 \\
27\end{array}$ & $\begin{array}{l}\text { Efficacy and safety of very early mobilization } \\
\text { within } 24 \text { h of stroke onset (AVERT): a randomized } \\
\text { controlled trial. }\end{array}$ & $386,46-55$ \\
\hline Carr \& Shepherd (2011). ${ }^{28}$ & $\begin{array}{l}\text { Enhancing Physical Activity and Brain } \\
\text { Reorganization after stroke. }\end{array}$ & $\begin{array}{l}\text { Neurol Res, Hindawi Publishing Corporation. } \\
\text { doi: } 10.1155 / 2011 / 515938\end{array}$ \\
\hline $\begin{array}{l}\text { McDermott \& Korner } \\
(2012) .{ }^{29}\end{array}$ & $\begin{array}{l}\text { Bilateral arm training in Stroke Engine } \\
\text { Intervention. Montreal: McGill University. }\end{array}$ & $\begin{array}{l}\underline{\text { http://strokengine.ca/intervention } / \text { index }} . \\
\text { php?page=topic\&id }=87\end{array}$ \\
\hline Schmidt \& Lee (2014). ${ }^{30}$ & Motor Learning and Performance. & $5^{\text {th }}$ Edition. Champaign, IL: Human Kinetics \\
\hline Nijland et al. (2010). ${ }^{31}$ & $\begin{array}{l}\text { Presence of finger extension and shoulder } \\
\text { abduction within } 72 \text { hours after stroke predict } \\
\text { functional recovery. }\end{array}$ & $\begin{array}{l}\text { Stroke. American Stroke Association. doi: } \\
\text { 10.1161/STROKEAHA.109.572065 }\end{array}$ \\
\hline Taylor \& Ivry (2012). ${ }^{32}$ & The role of strategies in motor learning. & $\begin{array}{l}\text { Ann N Y Acad Sci. doi: 10.1111/j.1749- } \\
6632.2011 .06430 . x \text {. }\end{array}$ \\
\hline
\end{tabular}


Implementation approach aspects of motor learning are 1) basic theories that support the importance of motor learning implementation in patients post ischemic stroke, 2) stage of motor learning, 3) motor learning principles, 4) dose, 5) the timing and 6) wide motor learning intervention (TABLE 2).

TABLE 2. Implementation approach aspects of motor learning

\begin{tabular}{|c|c|}
\hline Items & Key points \\
\hline \multirow{6}{*}{$\begin{array}{l}\text { Basic theories that support the } \\
\text { importance of motor learning } \\
\text { implementation in patients } \\
\text { post ischemic stroke }\end{array}$} & $\begin{array}{l}\text { 1. Motor learning and neurorehabilitation allow the plasticity of neurons and } \\
\text { motor system circuit as a result of a series of motion in exercises. }{ }^{15}\end{array}$ \\
\hline & $\begin{array}{l}\text { 2. Physical conscious experience is great for modulating neural plasticity in } \\
\text { the nervous system of post-stroke. }{ }^{14}\end{array}$ \\
\hline & $\begin{array}{l}\text { 3. Learning motor refers to a permanent change in the performance of individ- } \\
\text { ual motors is generated from exercise. }{ }^{16,17}\end{array}$ \\
\hline & $\begin{array}{l}\text { 4. Stimulation of the brain is able to bring the potential of adaptive plastic that } \\
\text { can accelerate the rehabilitation outcomes of stroke, because at the time of } \\
\text { the primary motor cortex (M1) and corticospinal damage then ipsilesional } \\
\text { premotor area (PMAs) can be used as his successor. }{ }^{18}\end{array}$ \\
\hline & $\begin{array}{l}\text { 5. Important principles of the reorganization of brain plasticity (physiological } \\
\text { and neuroanatomical reorganisation) have an impact in designing rehabili- } \\
\text { tation intervention. }{ }^{19}\end{array}$ \\
\hline & $\begin{array}{l}\text { 6. If two or more stimulus is given and then amplified together can cause learn- } \\
\text { ing association, it is possible to connect the two aspects of the motor that } \\
\text { occur at the same time (eg. hip joint extension to flexion of the knee joint). }{ }^{24}\end{array}$ \\
\hline \multirow[t]{2}{*}{ Stage of motor learning } & $\begin{array}{l}\text { 1. Motor learning refers to the three stages, namely the cognitive stage, asso- } \\
\text { ciative stage and autonomous stage. }{ }^{32}\end{array}$ \\
\hline & $\begin{array}{l}\text { 2. The presence of cortical representation as a result of learning and new skills } \\
\text { is their stage of progression of cognitive level to the level of automatic dis- } \\
\text { play smooth. }{ }^{16,22}\end{array}$ \\
\hline
\end{tabular}

Motor learning principles

1. Principle of motor learning help identify how to manipulate, tasks and a good environment that can affect the long-term neuroplasticity changes to improve the performance of individual motors. ${ }^{21}$

2. Using the principles of motor learning with a variety of tasks in the exercises have an important role to positive results, another principles are repetition, feedback and others. ${ }^{13}$

3. The important principle is the repetition of movements that would form the motor activity in cortical areas. ${ }^{20}$

4. The theory of motor learning encourage their active participation, practice and goal-oriented, which is essential from a learning. ${ }^{23}$

5. The effective collaboration of the various methods is needed to be optimal results. ${ }^{26}$

Dose

1. Physiotherapy conducted two times per week for 60 minutes for 10 weeks can improve motor function, postural balance, walking speed and quality of life post stroke. ${ }^{25}$

2. Systematic Review indicated that a dose of 30-60 minutes per day performed 5 to 7 days a week is more effective. It was also reported that the results were significantly associated with a faster time to therapy after the stroke. ${ }^{25}$ 
The timing
1. Mobilization after 24 hours after the attacks recommended for patients with post-stroke. ${ }^{27}$

2. The early mobilization is recommended for acute stage of stroke begins within 24 to 48 hours if there is no development of neurological deficits. Exercise with low intensity, low duration and low frequency conducted for at least 30 minutes to 1 hour per day. Exercises done to help patients get out of bed into a sitting position, standing or walking. ${ }^{28}$

Wide motor learning inter- 1. Bilateral Training allows the connection interlimb and mind so that it will vention facilitate the acceptance cerebral hemispherium brain activation of hemispherium damage and improve motor control. ${ }^{29}$

2. Repetitive Task Training can increase the activity of neural pathways, underlying the specific functions and improve practices in the task. ${ }^{30}$

3. CIMT focused on practical movement of the arms and hands of lesions in certain periods to obtain optimal motor repairs. ${ }^{31}$

4. Rood Method can be applied to regulate motor behavior due to the interaction between the somatic, autonomy and physical factors. This method uses a peripheral input to facilitate the movement and evoked postural response (provides sensory stimulation and teaches stage normal movement of the basic movement towards complex movements).

5. The method of PNF can be administered by contracting the muscles actively to provide proprioceptive stimulus, increasing the excitation and recruitment of motor units.

6. The method of Brunnstrom can be applied using a primitive reflex to initiate movement and support the future use of the pattern in the early stages of repair, restore movement realized through the activity of reflexes and sensory stimulation.

7. The Bobath Method can be applied to control the afferent input and facilitating normal postural reactions. Afferent input is used to improve the quality of movement, especially on the side of the lesion. Facilitation of postural reactions are used to provide an experience that normal movement (due to abnormal movement comes from abnormal tone). Tonus was also influenced by the change / setting the position and movement of the proximal joints.

8. Johnstone Method can be applied with the aim to control spasticity by inhibition of abnormal patterns and uses the setting position to influence the tone. It is assumed that the postural reflexes damage can be controlled by setting the position.

9. Carr and Shepherd's Methods have the assumption that the motor control of posture and movements are interrelated and will help modulate sensory input motor response to a task. This method can be applied in a way the patient performs active learning. Exercises based on biomechanical analysis of movements and exercises with specific contexts.
Experts consisted of neurologist, medical rehabilitation specialists and physiotherapists who had been in the case of neurology. The expert team consists of 4 neurologists,
1 medical rehabilitation specialist and 8 physiotherapists. Characteristics of the experts team are shown in TABLE 3, while register as a team of experts is shown in TABLE 4. 
TABLE 3. Characteristics of a team of experts:

\begin{tabular}{lc}
\hline Characteristics & Number \\
\hline Education & 5 \\
S3 & 3 \\
S2 & 5 \\
Expert & \\
Years of service & 13 \\
More than 5 years & 0 \\
Less than 5 years & \\
Experience & 5 \\
Lecturer and Practice & 5 \\
Practice & \\
Expertise & 5 \\
Neurologist & 1 \\
Medical Rehabilitation & 8 \\
Physiotherapist & \\
\hline
\end{tabular}

TABLE 4. Register as a team of experts

\begin{tabular}{|c|c|c|}
\hline Name & Expertise & Information \\
\hline Samekto Wibowo & Neurologist & $\begin{array}{l}\text { Promotor and Neurologist in Dr. Sardjito General } \\
\text { Hospital, Yogyakarta }\end{array}$ \\
\hline Ismail Setyopranoto & Neurologist & $\begin{array}{l}\text { Co-Promotor and Neurologist in Dr. Sardjito } \\
\text { General Hospital, Yogyakarta }\end{array}$ \\
\hline Suroto & Neurologist & $\begin{array}{l}\text { Neurologist in Dr. Moewardi District Hospital, } \\
\text { Surakarta }\end{array}$ \\
\hline Rusdi Ghozali & Neurologist & $\begin{array}{l}\text { Neurologist in Dr. Sardjito General Hospital, } \\
\text { Yogyakarta }\end{array}$ \\
\hline Noer Rachma & $\begin{array}{l}\text { Medical } \\
\text { Rehabilitation } \\
\text { Specialists }\end{array}$ & $\begin{array}{l}\text { Medical Rehabilitation Specialist in Dr. Moewardi } \\
\text { District Hospital, Surakarta }\end{array}$ \\
\hline Luklu Marianto & Physiotherapist & $\begin{array}{l}\text { Physiotherapist of Neurology in Dr. Moewardi } \\
\text { District Hospital, Surakarta }\end{array}$ \\
\hline Heru Purbo Kuntono & Physiotherapist & $\begin{array}{l}\text { Physiotherapist of Neurology and Lecturer Health } \\
\text { Polytechnic, Surakarta }\end{array}$ \\
\hline Setiawan & Physiotherapist & $\begin{array}{l}\text { Physiotherapist of Neurology and Lecturer Health } \\
\text { Polytechnic Surakarta }\end{array}$ \\
\hline Oki Pram Seciora & Physiotherapist & $\begin{array}{l}\text { Physiotherapist of Neurology in Private Practice in } \\
\text { Jakarta }\end{array}$ \\
\hline Parmono Dwi P & Physiotherapist & $\begin{array}{l}\text { Physiotherapist of Neurology and Physiotherapist } \\
\text { RS Islam Jakarta }\end{array}$ \\
\hline Agus Suyono, Bobath Certified & Physiotherapist & $\begin{array}{l}\text { Physiotherapist of Neurology and Physiotherapist } \\
\text { RS Hermina Jakarta }\end{array}$ \\
\hline I Made Gede Swardika & Physiotherapist & $\begin{array}{l}\text { Physiotherapist of Neurology and Physiotherapist } \\
\text { RS Cipto Mangunkusuma Jakarta }\end{array}$ \\
\hline Wisnu Praseyto Adhi & Physiotherapist & $\begin{array}{l}\text { Physiotherapist of Neurology - Bobath practitioners } \\
\text { for adult cases }\end{array}$ \\
\hline
\end{tabular}


Formulate the content validation resulted based on the consensus of experts based on the value of the CVR and CVI is shown in TABLE 5.

\section{Statement}

CVR

1. Motor learning and neurorehabilitation allow the plasticity of neurons and motor system circuit as a result of a series of motion in exercises ${ }^{15}$. The above statement is required as the basis for the theory that supports the need for a motor learning approach.

2. Physical conscious experiences is great for modulating neural plasticity in the nervous system of post-stroke. ${ }^{14}$ The above statement is required as the basis for the theory that supports the need for a motor learning approach.

3. Motor learning refers to the three stages, namely the cognitive stage, associative stage and autonomous stage. ${ }^{32}$ The above statement is required as the basis for the theory that supports the need for a motor learning approach.

4. Motor learning refers to a permanent change in the performance of individual motors is generated from exercise. ${ }^{16,17}$ The above statement is required as the basis for the theory that supports the need for a motor learning approach.

5. Brain stimulation is able to bring the potential adaptive plastic that can accelerate the rehabilitation outcomes of stroke, because at the time of the primary motor cortex (M1) and corticospinal damage then ipsilesional premotor area (PMAs) can be used as his successor. ${ }^{18}$ The above statement is required as the basis for the theory that supports the need for a motor learning approach.

6. Important principles of the reorganization of brain plasticity (physiological and neuroanatomical reorganisation) have an impact in designing rehabilitation intervention. ${ }^{7}$

The above statement is required as the basis for the theory that supports the need for a motor learning approach.

7. The important principle is the repetition of movements that would form the motor activity in cortical areas. ${ }^{20}$ The above statement is required as the basis for the theory that supports the need for a motor learning approach.

8. Principles of motor learning helps identify how to manipulate, tasks and a good environment that can affect the long-term neuroplastic changes to improve the performance of individual motors. ${ }^{21}$ The above statement is required as the basis for the theory that supports the need for a motor learning approach.

9. Using the principles of motor learning with a variety of tasks in the exercises have an important role to positive results, another principles are repetition, feedback and others. ${ }^{13}$ The above statement is required as the basis for the theory that supports the need for a motor learning approach.

10. The presence of cortical representation as a result of learning and new skills is their stage of progression of cognitive level to the level of automatic display smooth. ${ }^{16,22}$

The above statement is required as the basis for the theory that supports the need for a motor learning approach.

11. The theory of motor learning, encourage their active participation, practice and goal-oriented, which is essential from a learning. ${ }^{23}$ The above statement is required as the basis for the theory that supports the need for a motor learning approach.

12. If two or more stimulus is given and then amplified together can cause learning association, it is possible to connect the two aspects of the motor that occur at the same time (eg hip joint extension to flexion of the knee joint). ${ }^{24}$

The above statement is required as the basis for the theory that supports the need for a motor learning approach. 
13. Physiotherapy conducted two times per week for 60 minutes for 10 weeks can improve motor function, postural balance, walking speed and quality of life after stroke. ${ }^{25}$

The above statement is required as theoretical basis of the dose of exercise that supports the need for a motor learning.

14. Systematic Review indicated that a dose of 30-60 minutes per day performed 5 to 7 days a week is more effective. It was also reported that the results were significantly associated with a faster time to therapy after the stroke. ${ }^{26}$

The above statement is required as theoretical basis of the dose of exercise that supports the need for a motor learning.

15. Mobilization after 24 hours after the attacks recommended for patients with post-stroke. ${ }^{27}$

The above statement is required as the basis for the theory that supports the need for a motor learning approach.

16. Early mobilization is recommended for acute stage of stroke begins within 24 to 48 hours if there is no development of neurological deficits. Exercise with low intensity, low duration and low frequency conducted for at least 30 minutes to 1 hour per day. Exercises done to help patients stand up from the bed to a sitting position, standing or walking. ${ }^{28}$

The above statement is required as theoretical basis of the dose of exercise that supports the need for a motor learning.

17. Bilateral Training allows the connection interlimb and mind so that it will facilitate the acceptance cerebral hemisperium activation of cerebral hemisperium damage and improve motor control. ${ }^{29}$

The above statement is required as the basis for the theory that supports the need for a motor learning approach.

18. Repetitive Task Training can increase the activity of neural pathways, underlying the specific functions and improve practices in the task. ${ }^{30}$

The above statement is required as the basis for the theory that supports the need for a motor learning approach.

19. CIMT focused on practical movement of the arms and hands of lesions in certain periods to obtain optimal motor repairs. ${ }^{31}$

The above statement is required as the basis for the theory that supports the need for a motor learning approach.

20. Rood Methods can be applied to regulate motor behavior due to the interaction between the somatic, autonomy and physical factors. This method uses a peripheral input to facilitate the movement and postural evoked responses (provide sensory stimulation and teach stage normal movement of the basic movement towards complex movements).

21. Method of PNF can be administered by contracting the muscles actively to provide proprioceptive stimulus, increasing the excitation and recruitment of motor units.

22. Brunnstrom Methods can be applied using a primitive reflex to initiate movement and support the future use of the pattern in the early stages of repair, restore movement realized through the activity of reflexes and sensory stimulation.

23. Bobath Methods can be applied to control the afferent input and facilitating postural reactions are normal. Afferent input is used to improve the quality of movement, especially on the side of the lesion. Facilitation of postural reactions are used to provide an experience that normal movement (due to abnormal movement comes from abnormal tone). Tonus was also influenced by the change / setting the position and movement of the joints proximal portion. 
24. Johnstone Methods can be applied with the aim to control spasticity by inhibition of abnormal patterns and uses the setting position to influence the tone. It is assumed that the damage postural reflexes can be controlled through the setting position.

25. Carr and Shepherd Method have the assumption that the motor control of posture and movements are interrelated and will help modulate sensory input motor response to a task. This method can be applied in a way the patient performs active learning. Exercises based on biomechanical analysis of movements and exercises with specific.

The above statement context are required as the basis for the theory that supports the need for a motor learning approach.

26. The effective collaboration in various methods is needed to lead optimal results. ${ }^{26}$

Application of motor learning development model after ischemic stroke is shown in FIGURE 2.

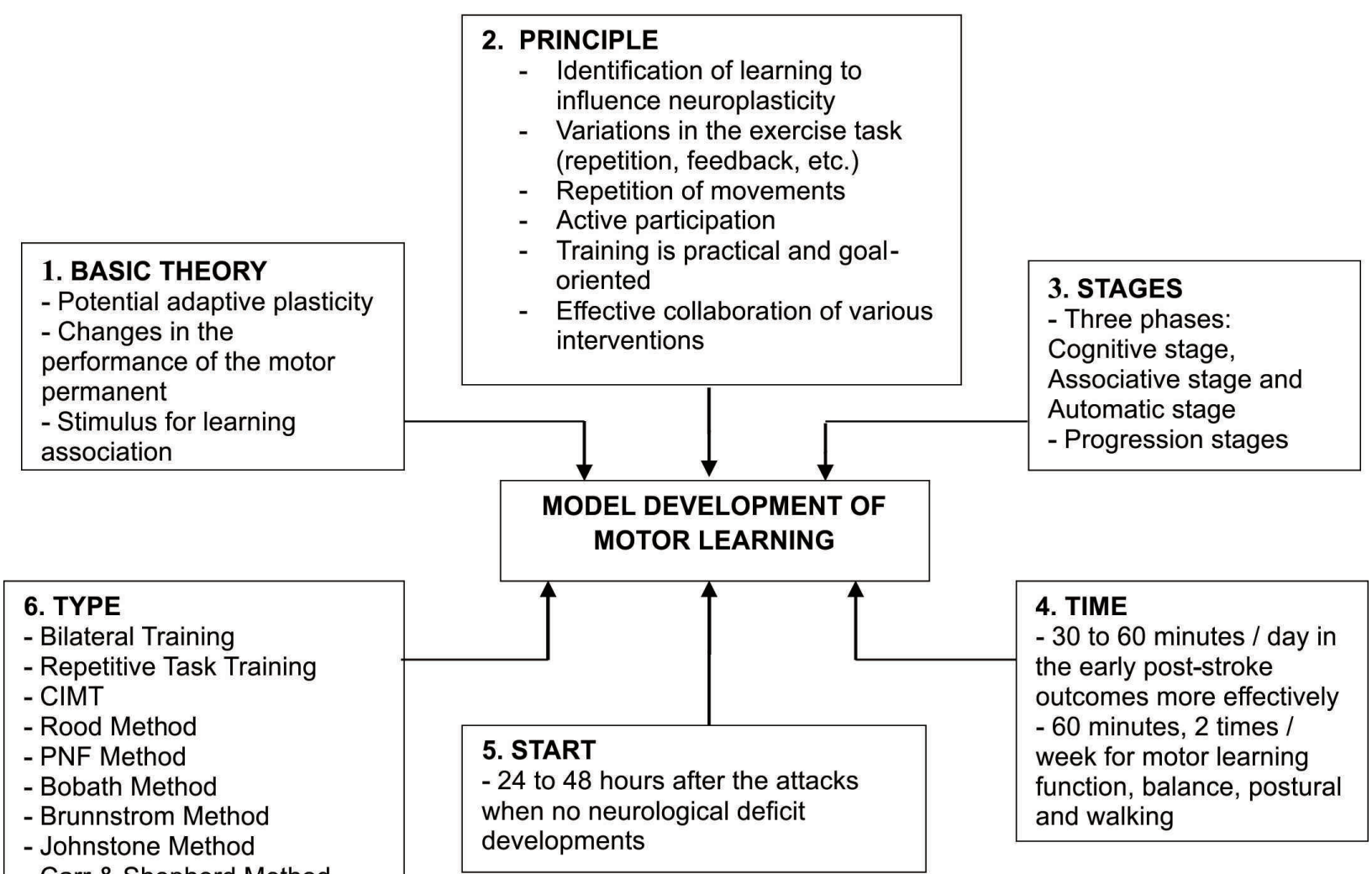

FIGURE 2. Application of motor learning development model after ischemic stroke 


\section{DISCUSSION}

The development model of motor learning approach was formulated based on certain stages. The first stage was to make the questionnaire form Content Validation Sheets derived from a literature review the results of previous studies of the 26 statements. There were some comments in the comments field of the experts associated with the added explanationoftheapplication ofmotorlearning, which has been formulated authors, namely 1). Application of motor learning, avoiding the wrong pattern and motion compensation. 2). Exercise with motor learning needs to be accompanied with a home program. 3). The best of approach method was adapted to the patient's problematic and condition. 4). Three aspects also need to be considered are sensory motor, cognitive/memory and psychological/ emotional. 5). Motor learning approach using functional movement patterns. 6). Motor learning approach is done depending on the type of stroke and the underlying disease (complicating factor). 7). The initial mobilization is done when hemodynamics has stabilized. 8). Restoration with very early mobilization determines the development of motor skills of patients. 9). Collaborate effectively from a variety of methods to involve the indispensable role of the family.

Comments from the experts was used as inputs in the points statement made by the author. The number of experts who participated in making this consensus was 13 experts in neurology, especially stroke treatment. Experts consist of neurologist, medical rehabilitation doctor and physiotherapist. Thirteen experts considered sufficient for such disclosed ${ }^{12}$ that based on the binomial probability, calculation of the value of the CVR 1 takes 5 to 7 experts panel. Once all the experts to fill Content Validation Sheets, then formulated a result of this consensus. The consensus formulation of the results was done by calculating the CVR and CVI. Results of CVR and CVI was used as the material to reach agreement/consensus on the relevance of the importance of grain this statement to be relied upon in formulating the neurorestoration form. Validation sheet fill in Likert Scale consisted of 5 levels of relevance, namely STP (very necessary), TP (unnecessary), C (Quite/could be necessary), $\mathrm{P}$ (required), SP (very necessary). Category STP, TP grouped in clusters that were not relevant, then the category C, P, SP grouped into relevant groups.

The questionnaire has been prepared in the Content Validation Sheet amounted to 26 point statement. Statements regarding the importance of implementing the linkage motor learning in post-ischemic stroke were formulated. CVR test results indicate a value of +1 for each of the 26-point statements. These showed that all grains are statement items than important and had a high relevance according to all the experts. All statements had a high validity for use as basis for the implementation of motor learning in postischemic stroke. Gilbert et al. ${ }^{11}$ demonstrated that when the value of the CVR 1:00 then all panelists/experts agree that it was an important item.

CVI test resulted from all statements related to the implementation of motor learning in post-ischemic stroke showed a value of +1 . This illustrates that the validation of the contents of the application statement grains motor learning was very relevant to post-ischemic stroke. A positive value of 1 indicated a very high relevance of the content validity of this, it was similar to the Polite recommendation that items having excellent content validity was the item that has a value of 0.78 or higher CVI. Beads of statements that have very high relevance were then grouped into sub-groups respectively. 
The subgroup includes six things:

1). Brain stimulation given through motor learning is able to bring the potential adaptive plastic that can accelerate the rehabilitation outcomes of stroke. This happens because when the primary motor cortex (M1) and corticospinal damage then ipsilesional premotor area (PMAs) can be used as his successor. ${ }^{18}$ In line with Hosp ${ }^{15}$ that the plasticity of neurons and the motor system circuitry allows occurs as a result of their range of motion in motor learning. Physical experience in motor learning, the conscious will modulate neural plasticity after stroke, ${ }^{14}$ will further provide permanent change in the performance of individual motors. ${ }^{16,17}$ If two or more stimulus is given and then amplified together can cause learning association, it is possible to connect the two aspects of the motor that occur at the same time (eg. hip joint extension to flexion of the knee joint). ${ }^{24}$ The essential principles of the reorganization $f$ brain plasticity could have implications in designing rehabilitation intervention. ${ }^{19}$

2). The basic principles about the importance of applying motor learning. Principle of motor learning is to help identify how to perform learning and a good environment that will affect the long-term neuroplastic changes in improving the performance of individual motors. ${ }^{21}$ The principle of the implementation of the various tasks in the exercise, repetition, providing feedback is essential. ${ }^{13}$ It is similar view was expressed by Bernstein ${ }^{20}$ that an important principle is the repetition of movements that would form the motor activity in cortical areas. Active participation, practice and goal-oriented is also essential from a learning. ${ }^{23}$ Application of motor learning by collaborating effectively on the various methods is also needed for optimal results lead. ${ }^{26}$

3). The stages that need to be considered in the application of motor learning. Representation cortical as a result of learning and new skills is their stage of progression of cognitive level to automatic display smooth level. ${ }^{16,22}$ In line with the Fits \& Posner in Taylor ${ }^{32}$ that motor learning refers to the three stages, namely the cognitive stage, associative stage and autonomous stage.

4). Timing of motor learning. The application of motor learning time is faster for 3060 minutes per day were carried out for 5 to 7 days per week indicates that more effective results. ${ }^{26}$ It was also reported that motor learning by physiotherapists who conducted two times per week for 60 minutes for 10 weeks can improve motor function, postural balance, walking speed and quality of life after stroke. ${ }^{25}$

$5)$. When is the commencement of the motor learning implementation? The early mobilization recommended for stroke patients in the acute stage. Mobilization can be done 24 hours after the attacks, ${ }^{27}$ 24 to 48 hours if there is no development of neurological deficits. Exercise with low intensity, low duration and low frequency conducted for at least 30 minutes to 1 hour per day. ${ }^{28}$

6). Various methods of intervention. The various motor learning intervention methods many developing concept. Besides, various methods of learning new motor skills emerge. All these methods have a slightly different philosophy but have the same goal in restoration of the damage. Each method has advantages in each concept. The difference advantage of this concept is very possible combined. Effective collaboration is needed to support optimal results. ${ }^{26}$ 
This Rood Method has the concept that the sensory and motor functions cannot be separated, so that the interaction between somatic, autonomy and physical factors play a role in regulating the behavior of the motor. This method is focused on the development stages of repair and use input peripherals to facilitate movement. While the PNF Method has the concept that actively contracting muscle intended to stimulate the proprioceptive afferent CNS thereby increasing the excitation and the addition of motor unit recruitment. The principle of this method is the use of diagonal pattern of active and passive movements. Tihe approach of Brunnstrom Method using primitive reflexes to initiate movement and support the future use of patterns in the initial stages of repair. Bobath approach has the objective to control afferent input and facilitating postural reactions are normal. The aim is to provide an experience that normal movement and when there is inhibition of afferent input abnormal movements in patients. Bobath approach is classified in neurodevelopmental technique is an original idea for reducing abnormal tone through positioning, handling techniques used to facilitate normal movement. ${ }^{33}$ Bilateral Arm Training Method simultaneously uses both activities the same arm movements at the same time. Variations of this form of exercise can be done. The use of mechanical or robotic assistance can also be done to move the active or passive on the arm lesion through the identification of the movement of the limb lesions. The key to this concept is connecting between the limbs, the mind to balance interhemisperium, activate hemisperium and improve motor control of the arm lesion. ${ }^{29}$ Other methods such as Constraint-Induced Movement Therapy (CIMT) or forced-use therapy have the concept that hands are not placed lesions in the arm sling, glove to prevent that is not used for smooth movement. ${ }^{34,35}$ Constraint of the hand that is not the lesion then all will use arm movements that lesions to improve a difficult task. Another approach to motor learning, which is Repetitive Task Training, this concept has the view that the increase in the activity of neural pathways underlying specific functions and improve practices in the task. ${ }^{30}$ Another method is the Mirror Therapy, which has the concept that the cortical areas of the brain will be active during the Mirror Therapy, the observation shows a picture of the action which is reflected in the absence of barriers to movement of the arm due to the influence excitability of the motor area of the arm in the area of the lesion. While other methods are Mental Practice used to improve the performance of specialized in sports such as dance and music, so the potential for benefits in the context of rehabilitation. Implementation methods of Mental Practice proved by the observation that people who are not experienced weakness will show the brain areas activated by actual movement, in observation and imagination, except in areas that are responsible for doing the actual movement. Carr and Shepherd Methods is a motor learning approach, which has the concept with the assumption that the motor control of posture and movement are interconnected and sensory input would help modulate motor response to a task. This method is done by active learning, using biomechanical analysis of movements and exercises with context specific.

\section{CONCLUSION}

Based consensus of experts, items of motor learning application model development for ischemic stroke is very relevant. Six indicators of the importance of applying motor learning, which is the basic theory behind the 
importance of intervention motor learning, motor learning stages, principles of motor learning, dosage, timing of and kinds of motor learning interventions that can be provided.

\section{ACKNOWLEDGMENTS}

We would like to thank for the support of many parties, especially all experts Nerve Specialist Doctors, Medical Rehabilitation Doctor and Physiotherapists who have given their views in reaching a consensus.

\section{REFERENCES}

1. Donnan GA, Fisher M, Macleod M, Davis, SM. Stroke. Lancet 2008; 371(9612): 1612-23. http://dx.doi.org/10.1016/S01406736(08)60694-7

2. Stein J, Harvey RL, Winsten CJ, Zodowitz RD, Wittenberg GF editors. Stroke recovery $\&$ rehabilitation. New York: Demos Medical Publishing, 2009.

3. Warlow C, Van GJ, Dennis M, Wardlaw JM, Bamford JM, Hankey GJ. Stroke: practical management. $3^{\text {rd }}$ Edition. Oxford: Blackwell Publising. 2008. http://dx.doi.org/10.1002/ 9780470696361

4. Langhorne P, Rudd AG. Stroke service: a global perspective. In: Stein J, Harvey RL, Winsten CJ, Zodowitz RD, Wittenberg GF editors, Stroke recovery \& rehabilitation. New York: Demos Medical Publishing. 2009.

5. Shaughnessy N, Michael K. Stroke in older adults. In: Stein J, Harvey RL, Winsten CJ, Zodowitz RD, Wittenberg GF editors, Stroke recovery \& rehabilitation. New York: Demos Medical Publishing. 2009.

6. Chen J, Venkat P, Zacharek A, Chopp M. Neurorestorative therapy for stroke. Front Hum Neurosci. 2014; 8:382. http:// dx.doiorg/10.3389/fnhum.2014.00382

7. Nudo RJ. Post-infarct cortical plasticity and behavioral recovery. Stroke 2007; 38 (2
Suppl):840-5. http://dx.doi.org/10.1161/01 . STR.0000247943.12887.d2

8. O'Sullivan SB, Schmitz TJ. Physical Rehabilitation: Assessment and Treatment. FA Davis Company. 1994.

9. Boyd LA, Vidoni ED, Wessel BD. Motor learning after stroke: is skill acquisition a prerequisite for contralesional neuroplastic change? Neurosci Lett 2010; 482(1):21-5. http://dx.doi.org/10.1016/j.neulet. 2010.06 . 082

10. Pollock A, Farmer SE, Brady MC, Langhorne $\mathrm{P}$, Mead GE, Mehrholz J, et al. Interventions for improving upper limb function after stroke. Cochrane Database Syst Rev 2014; 12(11):CD010820. http://dx.doi. org/10.1002/14651858.CD010820

11. Gilbert GE, Prion S. Making sense of methods and measurement: lawshe's content validity index. Clin Simul Nurs 2016; 12: 530-1. http://dx.doi.org/10.1016/ j.ecns.2015.12.013

12. Ayre C, Scally AJ. Critical values for lawshe's content validity ratio: revisiting the original methods of calculation. Meas Eval Couns Dev 2014; 47(1):79-86. http://dx.doi. org/10.1177/0748175613513808

13. Darekar A, McFadyen BJ, Lamontagne A, Fung J. Efficacy of virtual realitybased intervention on balance and mobility disorders post-stroke: a scoping review. J Neuroeng Rehabil 2015; 12:46. http://dx.doi. org/10.1186/s12984-015-0035-3

14. Hu XL, Tong KY, Wei XJ, Rong W, Susanto EA, Ho SK. The effect of post-stroke upperlimb training with an electromyography (EMG)-driven hand robot. J Electromyogr Kinesiol 2013; 23(5):1065-74. http://dx.doi. org/10.1016/j.jelekin.2013.07.007

15. Hosp JA, Luft AR. Cortical plasticity during motor learning and recovery after ischemic stroke. Neural Plast 2011; 2011:871296. http://dx.doi.org/10.1155/2011/871296 
16. Wishart LR, Lee TD, Ezekiel HJ, Marley TL, Lehto NK. Application of motor learning principles: the physiotherapy client as a problem-solver. 1. Concepts. Physiother Can 2000; 52:229-32.

17. Letho NK, Marley TL, Ezekiel HJ. Application of motor learning principles: the physiotherapy client as a problem-solver. IV. Future directions. Physiother Can 2001; 10914.

18. Plow EB, Cunningham DA, Varnerin $\mathrm{N}$, Machado A. Rethinking stimulation of the brain in stroke rehabilitation: why higher motor areas might be better alternatives for patient with greater impairments. Neuroscience 2015; 21(3):225-40. http:// dx.doi.org/10.1177/1073858414537381

19. Nudo RJ. Neural bases of recovery after brain injury. J Commun Disord 2011; 44(5):515-20. http://dx.doi.org/10.1016/j. jcomdis.2011.04.004

20. Bernstein NA: Translate by Mark L Latash. With on dexterity and its development lawrence erlbaum associates. New Jersey: Publishers Mahwah, 1996.

21. Muratori LM, Lamberg EM, Quinn L, Duff SV. Applying principles of motor learning and control to upper extremity rehabilitation. J Hand Ther 2013; 26(2):94-103. http://dx.doi. org/10.1016/j.jht.2012.12.007

22. Halsband U, Lange RK. Motor learning in man: a review of functional and clinical studies. J Physiol 2006; 99(4-6):414-24. http:// dx.doi.org/10.1016/ j.jphysparis.2006.03.007

23. Winstein CJ, Merians A, Sullivan KJ. Motor learning after unilateral brain damage. Neuropsychologia 1999; 37(8):975-87.http:// dx.doi.org/10.1016/S0028-3932(98)00145-6

24. Johansson BB. Neurorehabilitation and brain plasticity. J Rehabil Med 2003; 35(1):1. http:// dx.doi.org/10.1080/16501970306105

25. Olaleye OA, Hamzat TK, Owolabi MO. Stroke rehabilitation: should physiotherapy intervention be provided at a primary health care center or the patients' place of domicile? Disabil Rehabil 2014; 36(1):49-54. http:// dx.doi.org/10.3109/09638288.2013.777804

26. Pollock A, Baer G, Campbell P, Choo PL, Forster A, Morris J, et al. Physical rehabilitation approaches for the recovery of function and mobility following stroke Cochrane Database Syst Rev 2014; 22(4):CD001920. http://dx.doi.org/10.1002/ 14651858.CD001920.pub3

27. AVERT Trial Collaboration Group. Efficacy and safety of very early mobilization within $24 \mathrm{~h}$ of stroke onset (AVERT): a randomized controlled trial. Lancet 2015; 386(9988):4655. http://dx.doi.org/10.1016/S01406736(15)60690-0

28. Carr JH, Shepherd RB. Enhancing physical activity and brain reorganization after stroke. Neurol Res Int 2011; 2011:515938. http:// dx.doi.org/10.1155/2011/515938

29. McDermott A, Korner BN. Bilateral arm training. In: Stroke Engine Intervention. Montreal: McGill University. 2012. http://strokengine.ca/intervention/ index. php?page $=$ topic \&id $=87$

30. Schmidt RA, Lee TD. Motor learning and performance. $5^{\text {th }}$ Edition. Champaign, IL: Human Kinetics, 2014.

31. Nijland RR, van Wegen EE, Harmeling-van der Wel BC, Kwakkel G. Precence of finger extension and shoulder abduction within 72 hours after stroke predict functional recovery: early prediction of functional outcome after stroke: the EPOS cohort study. Stroke 2010; 41(4):745-50. http:dx.doi.org/10.1161/ STROKEAHA.109.572065

32. Taylor JA, Ivry RB. The role of strategies in motor learning. Ann N Y Acad Sci 2012; 1251:1-12. http://dx.doi.org/10.1111/j.17496632.2011.06430.x

33. Raine S, Meadows L, Ellerington M. Bobath Concept: theory and clinical practice in 
neurological rehabilitation. Oxford: WileyBlackwell, 2009. http://dx.doi.org/10.1002/ 9781444314601

34. Uswatte G, Taub E, Morris D, Barman J, Crago J. Contribution of the shaping and restraint components of constraint-induced movement therapy to treatment outcome. NeuroRehabilitation 2006; 21(2):147-56.
35. Wolf SL, Butler AJ, Alberts JL, Kim MW. Contemporarylinkages betweenEMG, kinetics and stroke rehabilitation. J Electromyogr Kinesiol 2005; 15(3):229-39. http://dx.doi. org/10.1016/j.jelekin.2005.01.002 